\title{
Environmental Impact of Produced Water and Driiling Waste Discharges from the Niger Delta Petroleum Industry
}

\author{
Ashe Kalli Gazali ${ }^{1}$, Abdulhamid Nur Alkali ${ }^{2}$ Yakubu Mohammed ${ }^{3}$ \\ Yaba Djauro ${ }^{4}$ Dahir D Muhammed ${ }^{5}$ and Mustapha kodomi ${ }^{6}$ \\ Geology Department, University of Maiduguri, ashekalligazali@gmail.com ${ }^{1}$ \\ Civil Engineering and water resources Department, University of Maiduguri abdulhamidalkali@yahoo.com ${ }^{2}$ \\ Geology Department, University of Maiduguri, yakubumohammed.94@yahoo.com ${ }^{3}$
}

\begin{abstract}
Exploratory discharge of produced water and drilling cuttings from oil and gas production has become a major source of pollutant to the biota. The aim of this study is to review previ-ous research on the environmental effect of such exploratory wastes with emphasis on the Niger Delta region. Drilling waste is composed of Aliphatic Hydrocarbon, Polynuclear Aro-matic Hydrocarbon (PAH) and heavy metals such as cadmium, chromium, lead, mercury, ar-senic, copper, Iron, lead, manganese, zinc, barium and strontium among others which are toxic to the environment. The composition and characteristics of naturally occurring chemical substances in produced water $(P W)$ are closely associated to the geological characteristics of each reservoir. The toxicity of produced water effluent can be reduced when treated before discharging into the sea. Sulphide reducing microorganism which are associated with pro-duced water pose threat to the environment. Barite and bentonite present in most drilling fluid were found to reduce plant growth. Studies in some part of the Niger delta have shown high level of some heavy metals associated with exploratory waste with concentrations higher than world health organization (WHO) standard; these have negative impact on the environment such as massive destruction to aquatic lives and agriculture.
\end{abstract}

Keywords: produced water, drilling waste, environmental impact, offshore and onshore

\section{INTRODUCTION}

Environmental deterioration is now a common and most devastating problem all over the world. Countries are focusing on executing environmental strategies in their working sur-roundings to ensure the wellbeing of nature's turf (Corbera et al., 2010). One of the immedi-ate physical environments that suffer the direct impact of drilling waste disposal is the on-shore and offshore (Gbadebo et al., 2010) .Since the discovery of oil in Nigeria in 1950s and its commercialization in 1958, oil exploration and exploitation has being ongoing in Nigeria (Kadafa et al., 2012). The region has huge oil and gas reserve. Anthropogenic activities re-lated to oil exploration and exploitation raise a number of issues such as depletion of bioder-visity, coastal and riverbank erosion, flooding, oil spillage, gas flaring, noise pollution, sewage and wastewater pollution, land degradation, soil fertility loss and deforestation which are all major environmental issues (Kadafa et al., 2012). Majority of Nigeria's oil and gas reserve is located along the Niger Delta River, Offshore Bright of Benin gulf of Guinea and Bright of bonny (Kadafa et al., 2012). Niger Delta region occupies the largest extension of freshwater swamps, is predominantly occupied by rural communities that depend solely on the natural environment for sustenance and livelihood (UNDP, 2006; Ogon, 2006). The region consist of areas covered by the natural delta of the river Niger and areas to the east and west which produces oil (Environmental resources man-agement (1997) and has a wetland of about 70,000sqkm (Sagay, 2001). According to Nwilo and Badejo (2004), the rapid development and production of the Niger delta discovered re-sources in terms of crude oil with associated population and industrialisation increase has re-sulted in environmental degradation in the region.

In 1958, Commercial quantities of oil were produced in Oloibiri, Bayelsa State which lead to the subsequent increase in exploration and production of hydrocarbon (Ohimain, 2003). These explorations consequently yielded a substantial amount of drilling wastes. Oil and gas exploration and production results in the increase of drilling waste which are basically the drilling mud, well cuttings, formation water (Produced water), cement slurry by product and oil cushions (Gbadebo et al., 2010). Niger Delta region is rated as the most oil impacted en-vironment and polluted area in the world by environmental experts from the UK, USA and Nigeria.(Kia, 2009; Ikelegbe, 2005; Obi 2000).This region has suffered all forms of pollution and degradation arising from exploration and production, and there are over 2,000 0il- pol-luted sites that need to be remediated (Baird, 2010). Fig 1 Map of Nigeria showing Niger Delta region. 


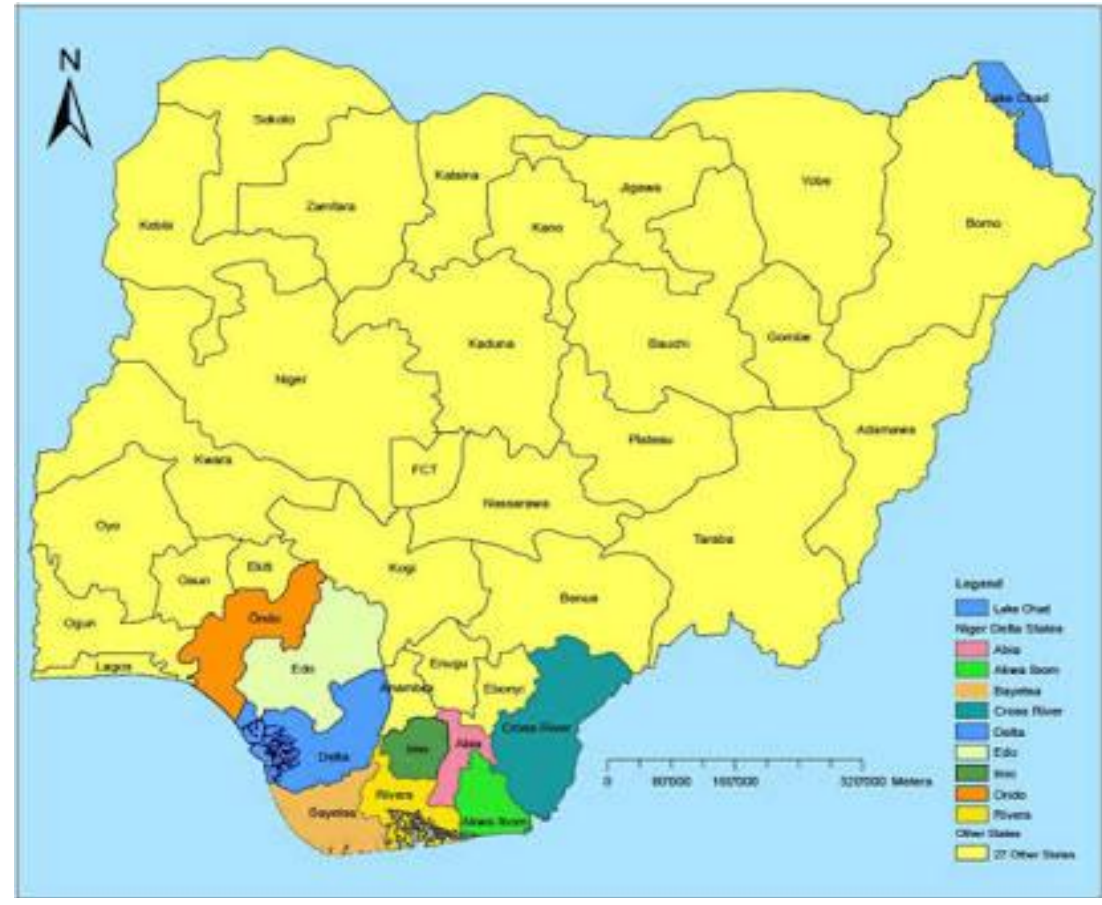

Fig 1. Map of Nigeria Showing the Oil Producing States in Niger Delta Region (excluding off shore Production beyond the lower limit of the Continental Shelf) (Aniefiok et al., 2013).

Produced water which is a by-product of oil and gas exploration, may contain dissolved sol-ids, bacteria, organic compounds, suspended solid and radioactive materials (Isehunwa and onova 2011; Okoro, 2010). Torgeir et al., (2011) opined that the large volume of this water being discharged, the complex content of some hazardous chemicals and lack of knowledge on its possible long term and ecological impact has made it the strongest issue of concern and research. Unsustainable disposal methods of such waste products could result in some adverse environmental impacts. In light of this, the Niger delta environment has become vulnerable to many environmental problems which could be attributed to poor environmental management strategy. Increase in petroleum exploration had resulted in the abuse of the environment. Environmental protection rules and regulations related to the oil industry in Nigeria appear not to have been functioning effectively (Ogri, 2001: Aniefiok et al., 2013). The envi-ronmental impact of the drilling waste in the Niger delta ecosystem calls for environmental concern (Benka and Olumagin, 1996). This review will focus on the environmental impact of produced water and drilling cuttings in the Niger delta petroleum industry and suggests some sustainable measures aimed at addressing the issues

\section{Produced Water (PW) and Drilling waste}

Produced water (also called formation water, brine or saltwater) is water from underground formations that is brought to the surface during oil or gas production. It is the largest volume of 568 by-products or waste stream associated with oil and gas exploration and production. The water is discharged in an oily form after its separation from the real oil. During oil and gas exploration other forms of wastewater are produced, these include injected water, little quantity of water that is condensed and traces of some chemicals used among which pro-duced water is the highest generated by-product. However, their production depends on the exploration area and formation type (Okoro, 2010). The physical and chemical properties of produced water vary considerably depending on the geographic location of the field, the geo-logic formation, and the type of hydrocarbon product being produced (Veil, 2015). Because the water has been in contact with hydrocarbon-bearing formations, it contains some of the chemical characteristics of the formations and the hydrocarbons. It may include water from the reservoir, water previously injected into the formation, and any chemicals added during the production processes. According to Bakke et al. (2013) the composition and characteris-tics of naturally occurring chemical substances in PW are closely associated to the geological characteristics of each reservoir. Produced water is mostly discharged to the immediate aquatic environment; the organic and inorganic compounds in produced water have higher toxicity to the environment than crude oil. The main pollutant of aquatic environment is produced water (Obire and Amusans 2003). According to Kaur et al., (2009) Sulphate reducing bacteria may also be present in PW. Okoro (2010) reported that sulphate reducing bacteria (SRB) and hydrocarbon utilizing micro- organism usually found in produced water have toxic effect to human, aquatic life and bacteria Fig.2 produced water being discharged to surface water. 


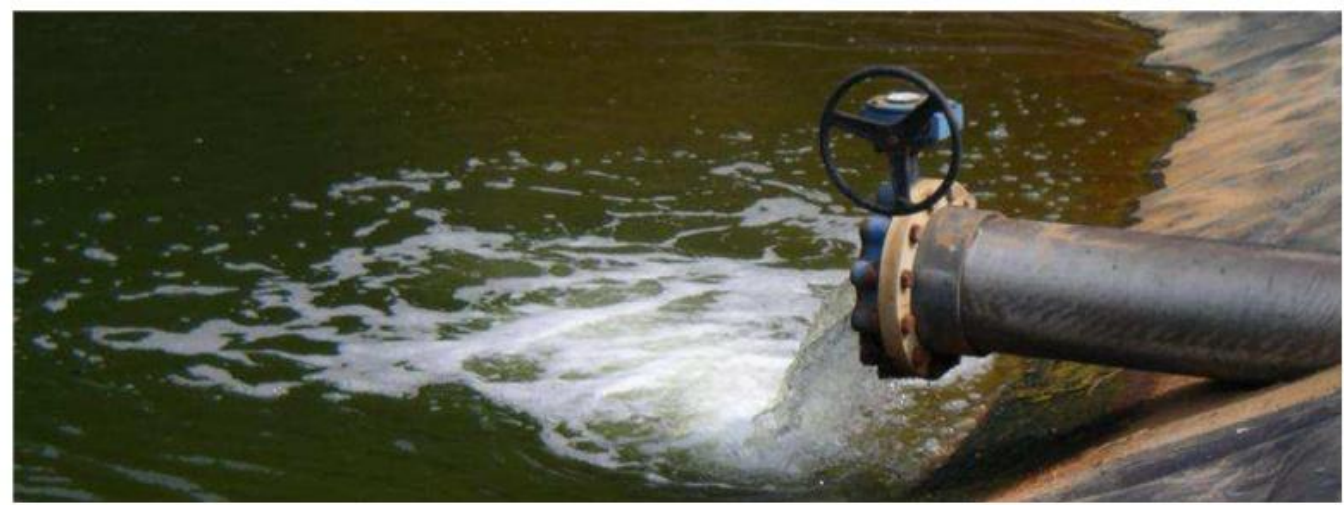

Figure: 2 produced water discharged to surface water (John, 2012)

Drilling waste consists of crushed rocks cuttings and mud remnants. The major components are liquid (water, oil or other organic fluids) and a weighting material (typically barite, BaSO4). Various additives are used to improve the technical performance of the mud. Among these are viscosifiers (eg poly-acrylates, and other organic polymers), emulsifiers (e.g alkylacrylate sulphonate and polyethylene oxide), $\mathrm{PH}$ and shale control agents, and de-flocculant (Davies and Kingston, 1992). Three main types of drilling mud are recognised wa-ter based muds (WBM) usually containing sea water as the base liquid, oil based muds (OBM) with either diesel oil or low-aromatic mineral oil as the base liquid, and synthetic muds (SM). According to Abdul Razak et al., (2017) synthetic based drilling fluid is pre-ferred due to its technical performance and minimal Environmental effects. Research has shown that OBM contain a wide array of organic and inorganic traces which are very hazard-ous to the environment (Wills, 2000).

The impacts of drilling fluid disposal on offshore waters are primarily physical. Research has proven that the discharge of bentonite and barite on the ground prevents plant growth (Kinigoma, 2001).The most common health effects from drilling fluild to human, is skin irri-tation and contact dermatites (IPIECA and OGP, 2009). One of the most common Environ-mental threats from drilling fluid waste is heavy metals; these may result to bioacumulation in aquatic organism Abdul Razak et al., (2017). Studies have showed that the growth of flora and Fauna was affected by the toxic heavy metals contamination in the Environment ( Sil et al., 2012 ).

\section{Composition of Produced Water}

The common compositions of wastes from exploration consist of aliphatic hydrocarbons and polynuclear aromatic hydrocarbons (PAH).PAH constitutes a diverse class of hydrophobic substance that are ubiquitous environmental contaminant (Harvey, 1997). Toxic metals asso-ciated with produced water are arsenic, copper, iron, lead, manganese, zinc, barium and strontium (Odeigah et al. 1997). This waste varies in their toxicities and impact on the ecology of the environment (Gbadebo et al. 2010). PW is also associated with a mixture of Chromium, Silver, Nickel, Lead, Iron, and radioactive materials (Isehuwa and Onovaes, 2011). A study of produced water in the western United States found that the oil and grease content range from $40 \mathrm{mg} / \mathrm{L}$ to $2,000 \mathrm{mg} / \mathrm{L}$ (Benko and Drewes 2010). According to Cline (1998), most produced waters are more saline than seawater. Benko and Drewes (2008) found the TDS concentration of produced water in the western United States to vary between $1,000 \mathrm{mg} / \mathrm{L}$ and $400,000 \mathrm{mg} / \mathrm{L}$. According to Kharaka and Otton (2003) the toxicity of produce water is directly related to high salinity $(3000$ to $>350,000 \mathrm{mg} / \mathrm{L}$ total dissolved solids (TDS).

\section{Water Discharged in the Niger Delta}

According to Isehuwa and Onovae (2011) discharged produced water in the Niger Delta as-sociated with gas condensate platform has high level of toxicity compared to produced water that are associated with oil platform. Produced water in offshore drilling are usually dis-charged to the immediate aquatic environment. Discharge of this waste water to freshwater environment affects agricultural resources and massive destruction to aquatic life (Obire and Amusan, 2003). During oil and gas production in Nigeria, about one billion barrels of pro-duced water is discharged per year (Isehunwa and onova, 2011). Produced water consists of dissolved solids, bacteria, organic compounds, suspended solid and radioactive materials (Isehunwa and Onova, 2011). It is assumed that $7500-11,500$ tonnes hydrocarbon is released to the environment yearly as a result of formation water discharges worldwide (Holdway, 2002). Considering the large volume of estimated hydrocarbon released worldwide to the en-vironment as a result of formation water discharges, this could alter the natural state of the environment which may lead to different forms of environmental problems. (Raji and Abejide , 2013) reported that the exploration and production of oil within the Niger Delta En-vironment has brought changes to their ecosystem. 


\section{Environmental Effects of Produced Water}

The effect of produced water (PW) in a certain environment depends on the physical, chemi-cal and biological composition of such environment. Findings indicate that in spite of all the level of toxicity of produced water effluent, there is paucity of information on their real im-pact on the exposed ecology ( Odeigah et al., 1997). In offshore drilling, (PW) are mostly discharged to the immediate aquatic environment. The organic and inorganic compounds in (PW) have higher toxicity compared to that of crude oil (Obire and Amusan , 2003). The dis-charge of these toxic constituents and contaminants to the aquatic environment pose threat to aquatic life and agricultural resources by altering the natural state of the aquatic environment (Obire and Amusan, 2003). Also, Ayotamuna et al. (2012) opined that discharge of the wastes to fresh water environment affects agricultural resources and causes massive destruc-tion to the aquatic life. Worldwide research has proven that produced water effluents are as-sociated with high level of biological oxygen demand (BOD) and chemical oxygen demand (COD) which are generated from compounds of fatty acids. Salinity is higher in produce wa-ter than some sea water which could result to aquatic destruction in fresh water ( Isehunwa and onovae , 2011). According to Neff et al. (2011) heavy metals and naturally occurring ra-dioactive material (NORM) associated with the PW could be of particular environmental concern.

Accordindg to Adewole et al., (2010) water based mud shows minimal impact on sea birds and aquatic life whereas oil based muds has long time effect. In most onshore operations, waste disposal was unethical. Drilling mud and cuttings were disposed to a waste pit which may overflow to nearby streams and rivers. Ayotamuno et al., (2002) studied ten wells in Ni-ger delta; they collected samples and analysed to examine the impact of discharged water and drilling cuttings on the onshore environment. Table 2 is the toxicity levels of waste generated in the ten wells visited during their research. The heavy metal chromium is mild in all studied effluents while iron was considerably higher than required level of 0.1 . Zinc level is low in all the samples while Mercury was not detected. Lead was detected in one of the well which was 24 times higher than the 0.05 (WH0) standards. Lead has poisonous effect when ingested by animals, which could result in neurological defects, kidney dysfunction and anaemia in humans (WHO, 2011). Nitrate, sulphate and phosphate within were found to conform to the WHO standard. Total dissolved solid was found to be very high which may affect the hardness of the water. The reduction in aquatic life in the study area was attributed to increasing level of waste discharge containing high level of Total dissolved solids (TDS) and trace metals. Okoro (2010) reported that the impact of produced water in an open sea is less due to the level of mixing and dilution compared to onshore environment where rate of mixing and dilution is less. According to OGP (2005) "naturally occurring radioactivity associated with produced water discharge represent an insignificant risk to marine life or human" stressing that there are many technological methods of managing and treating produced water. A study by Jonathan (2000) reveal that produced water is associated with very toxic polynuclear aromatic hydrocarbons which might not be removed by treatment. However, Torgeir et al., (2013) reported that the large volume of PW discharge, its complex content, which may be hazardous coupled with the lack of knowledge on its possible long term and ecological impact has made produced water discharges the strongest issue for concern.

According to the 1994 Exploration and Production (E \& P) forum report in Jonathan (2000), all produced water can be regarded as non-toxic, due to low toxicity of its pollutants and con-sidering the rapid dilution and mixing ability of sea water. However in the same report, Greenpeace Argued that the oil carried in produced water is more toxic than the petroleum itself, the research reveals that there are significant effects of produced water discharges on plank tonic larvae which are caused by produce water plumes. Ecotoxicological issues related to PAH have been investigated in detail for many years and have been reported in a high number of scientific papers and reviews. PAH may cause DNA damage (Aas et al., 2000a), oxidative stress (Sturve et al., 2006) and cardiac function defects (Incardona et al., 2004). Some PAH may form DNA adducts and neoplasia in fish liver through metabolic intermedi-ates (Myers et al., 1991). Compounds present in PW have a potential to exert endocrine ef-fects in fish Bakke et al., (2013). Meier et al. (2010) still concluded that widespread and long lasting xenosstrogenicity and reproduction effects of PW on the population level in fish are unlikely. This was also supported by Sundt et al. (2011) who compared data from PW-exposed fish in the laboratory to a similar data in an oil field. According to Scheren et al., (2002) the major environmental issues arise primarily from the improper discharge of pro-duced water and drilling cuttings.Roach et al., (1992) reported that adverse impact to man-grove vegetation in Niger delta are the most obvious signs of environmental effects resulting from produced water spills and discharges.

Some petroleum drilling wastes table 1 and effluent characteristics of some wells are shown in table 2. 
Environmental Impact of Produced Water and Driiling Waste Discharges from the Niger Delta ..

TABLE 1: Composition of petroleum drilling waste in Nigeria

\begin{tabular}{|l|l|l|}
\hline Solids & Liquids & Emission \\
\hline Cuttings & Mud/chemicals & Noise \\
Shaker screens & Accidental oil spills & Gas flaring \\
Perforating gun remains & Hydraulic spills & Cement dust \\
Wood and metal containers & Greases & Welding-gases and fumes \\
Metal scrap & Flammable paints / & \\
Radio-active waste & Thinners & \\
Filters and machinery parts & Lube oils & \\
Glass & Produced water & \\
Batteries & Acid wastes & \\
Condemned pipes & Cement slurry & \\
Fire extinguisher accessories & & \\
& & \\
\hline
\end{tabular}

(Ayotamuno et al., 2002)

TABLE: 2 Effluent characteristics obtained from the ten wells studied in Niger delta com-pared to WHO standard for treated water (Ayotamuno et al., 2002).

\begin{tabular}{|l|l|l|l|l|l|l|l|l|l|l|l|}
\hline Parameters & W1 & W2 & W3 & W4 & W5 & W6 & W7 & W8 & W9 & W10 & WHO \\
\hline PH & 6.6 & 6.8 & 6.1 & 6.3 & 5.1 & 6.4 & 6.5 & 6.4 & 6.6 & 6.4 & $7-8$ \\
\hline Temp & 29 & 27.8 & 29.5 & 30.8 & 26.5 & 36.5 & 30.3 & 28.3 & 36.5 & 24.4 & $<35$ \\
\hline Calcium & 200 & 305 & 245 & 350 & 325 & 520 & 270 & 290 & 317 & 29.4 & 75 \\
\hline Chloride & 500 & 475 & 302 & 605 & 550 & 480 & 875 & 322 & 812 & 220 & 200 \\
\hline Iron & 0.87 & 0.85 & 0.70 & 0.84 & 0.73 & 0.88 & 0.89 & 0.81 & 0.39 & 508 & 0.1 \\
\hline Lead & 1.21 & 0.09 & 0.02 & 1.23 & 0.06 & ND & ND & ND & ND & 0.73 & 0.05 \\
\hline Zinc & 0.98 & 1.79 & 1.62 & 1.71 & 2.20 & 0.21 & 0.29 & 0.41 & 214 & 0.08 & 5.0 \\
\hline Manganese & 1.82 & 1.54 & 0.96 & 1.96 & 0.06 & 1.96 & 0.94 & 0.91 & 0.46 & 2.00 & 0.1 \\
\hline Mercury & ND & ND & ND & ND & ND & ND & ND & ND & ND & 1.26 & 0.01 \\
\hline Chromium & 0.01 & 0.01 & 0.01 & 0.03 & 0.01 & 0.10 & 0.01 & 0.02 & 0.01 & 0.01 & 0.05 \\
\hline Nitrate & 0.45 & 1.02 & 0.62 & 0.92 & 1.00 & 1.20 & 0.23 & 0.62 & 0.62 & 1.20 & 10 \\
\hline Phosphate & 0.96 & 1.60 & 0.88 & 1.50 & 2.00 & 0.77 & 0.95 & 1.80 & 18.2 & 2.11 & - \\
\hline Sulphate & 95.2 & 1004 & 101 & 85.6 & 71.4 & 95.2 & 86.8 & 120.3 & 110.4 & 130.1 & 400 \\
\hline TDS & 2400 & 3300 & 2500 & 4200 & 4100 & 3700 & 3600 & 800 & 2400 & 4100 & 500 \\
\hline BODS & 7.5 & 11 & 9.2 & 15 & 6.3 & 9.0 & 10 & 12 & 9.5 & 13 & 4 \\
\hline Turbidity & 4 & 4 & 2 & 5 & 3 & 5.5 & 5.0 & 35 & 3.0 & 5.0 & 1 \\
\hline Oil/grease & 450 & 670 & 500 & 320 & 620 & 1100 & 250 & 850 & 240 & 180 & $<10$ \\
\hline
\end{tabular}

Temperature results is in $0 \mathrm{C}$ while all other results are in $\mathrm{mg} / \mathrm{L}$

The measure of $\mathrm{pH}$ does not have a major health or sanitary effect except for excessive values that indicate the acidity or alkalinity of the water. These may have organoleptic consequences. The $\mathrm{pH}$ level is also important for the life expectancy of fish.

The range suitable for fisheries is considered to be 5.0 to 9.0 (EPA, 2001). All the ten wells are within the set standard by WHO with the lowest being 5.1 in well 5 and the highest being 6.8 in well 2. High levels of Calcium content in water influences the hardness of the water. This factor brings about the wastage of detergents since they don't lather readily. All the wells except for Well 10 are above the recommended $75 \mathrm{mg} / 1$. The chloride content in all the wells is above the $200 \mathrm{mg} / \mathrm{l}$ requirement. High chloride content tends to make the water salty and will become increasingly objectionable as the concentration rises further. The iron content in water has a more significant effect in terms of colouration. Excess iron content stains laun-dry and also discolours vegetables on cooking. It may also affect the taste and also has a reac-tion on waters used to make tea (in which tannins are present) giving rise to off- colours re-sembling ink. From the results in Table 2, it is apparent that all the wells have Iron content above the recommended WHO standard. The presence of Lead on the other hand, contains a toxic cumulative poison which accumulates in the body tissue. It has extensively been related to kidney failures in several researches. The results show that wells 1, 2, 4, 5 and 10 have lim-its of Lead concentration exceeding the standard. The objections to Manganese, like Iron are purely aesthetic. Well 5 is the only well that exceeds the standard. Mercury on the other hand is highly toxic and is only found in well 10 . The hazard of this is magnified by the accumula-tion of organo -mercury compounds in fish. Chromium, also toxic and is associated with skin irritation, death of livestock resulting from chromium contaminated water have also been re-ported from time to time. It can be seen from the results that none of the wells is below the required 
standard. The Nitrate content in all the wells are within the limits of safety. Nitrates are hazardous to infants. Phosphates do not have much impact on the health but promotes the growth of algae (EPA, 2001) Well 2 has a high sulphate content of $1004 \mathrm{mg} / \mathrm{l}$ and exceeds the recommended $400 \mathrm{mg} / \mathrm{l}$ established by WHO. Excess sulphate has a laxative effect, especially in combination with magnesium and/or sodium. All the ten wells have requirements above $500 \mathrm{mg} / \mathrm{l}$ requirement. The effects of TDS are principally organoleptic. The turbidity of all the wells is also above the recommendation which may also interfere with the treatability of wa-ters.

\section{CONCLUSION AND RECOMMENDATIONS}

The vulnerability of Niger delta to different forms of environmental problems such as oil spillage, pollution and environmental degradation is associated with increase in oil and gas production activities coupled with improper drilling waste discharge and lack of compliance with environmental safety standards. These led to increase in the level of toxicity, impact of such wastes on the environment result in reduction of plant growth, destruction of aquatic life, human health problems and socio economic vices. The release of some toxic metals like Iron, Manganese, Chromium, Copper and other elements are hazardous to the environment and when consumed by fish through the food chain and consumed by humans can cause Can-cer, neurological disorder and other complications. Despite all the toxicities of PW and drill-ing wastes, its impact can be reduced by compliance with the Department of Petroleum Re-sources (DPR) and other environmental agencies standards. Also, the toxicity can be reduced by treating produced water before discharging into the sea. Government should construct a drilling waste treatment plant and set up an agency that will monitor the activities of the drill-ing industries. The treatment plant should encouraged oil and gas industries to make use of synthetic mud which has a less hazardous effect on the environment. It is also strongly rec-ommended that an integrated and multidisciplinary research be initiated to study this linger-ing issue in order to come up with an allencompassing strategy and resolution. Oil explora-tion companies in some parts of the world have adapted a strategy of produce water treatment before discharge and comparing the produce water treated with the constituent of water body to which it will be discharge to mitigate its impact, In Nigeria such strategy are not common. This strategies need to be adapted in Nigeria in other to safe guard the already deteriorating environment.

\section{REFERENCES}

[1]. Aas, E., Bausant, T., Balk, L., Liewenborg,B., Anderson, O.K., (2000a) “PAH Metabolites in bite , Cytochrome pusola and DNA adducts as Environmental risk parameters for chronic oil exposure : a laboratory experiment with Atlantic cod"' Journal of Aquatic toxicol (51) 241-258.

[2]. Abdul Razaq, I., Abdul Hadi, A., Wan Rosli, W., Mohd Zaidi.,J Issham, I (2017) “ Drilling Fluid Waste Management in Drilling for Oil and Gas Wells' Italian Association of chemical Engineering 56 Online at www.aidic.it/cet

[3]. Adewole, G. M., Adewale, T. M., and Ufuoma, E. (2010) 'Environmental aspect of oil and water-based drilling muds and cuttings from Dibi and Ewan Off-Shore wells in the Niger Delta, Nigeria 'African Journal of Environmental Science and Technology 4 (5): 284-292

[4]. Aniefiok, E.Ite., Udo.,J .Ibok., Margaret, U.Ite., Sunday, W. Peters (2013) ' Petroleum Exploration and Production: Past and Present Environmental issues in the Nigeria's Niger Delta',American Journal of Environmental Protection 1(4) 78-90

[5]. Ayotamuno, M., Akor, A., and Igho, T. (2002) 'Effluent Quality and Wastes from Petroleum Drilling Operations in the Niger Delta, Nigeria'. Environmental Management and Health 13 (2) 207-216

[6]. Baird, J., "Oil's Shame in Africa," Newsweek, 156 (4) 27-27

[7]. Bakke, T., Klungsoyr, J. and Sanni, S. (2013) "Environmental impacts of produced water and drilling waste discharges from the Norwegian offshore petroleum industry 'Marine envi-ronmental research (92) 154-169

[8]. Benka-Coker, M. and Olumagin, A. (1996) 'Effects of Waste Drilling Fluid on Bacterial Iso-lates from a Mangrove Swamp Oil field Location in the Niger Delta of Nigeria'. Bioresource Technology 55 (3): 175-179

[9]. Benko, K. L. and Drewes, J. E., (2010), “An Integrated Framework for Treatment and Man-agement of CBM Produced Water", 17th International Petroleum and Biofuels Environment Conference (IPEC), San Antonio, Texas, USA.

[10]. Cline, J., (1998) Treatment and discharge of produced water for deep offshore disposal. Paper presented at the API produced water Management technical forum and Exhibition.November 17-18, Lafayette, LA, USA.

[11]. Corbera, E., Estrada, M.,and Brown, K. (2010). Reducing greenhouse gas emissions from deforestation and forest degradation in developing countries: revisiting the assumptions. Cli-matic change, 100(3):355-388

[12]. Davies, J.m., and Kingstone, P.F (1992) "Sources of Environmental disturbance associated with Offshore Oil and Gas developments" in: Carns, W.J. (ed) North sea Oil and the Envi-ronment: Developing oil and Gas Resources, Environmental impacts and Responses. Univer-sity press Cambridge.

[13]. Environmental Protection Agency, (2001) "Parameters of Water Quality- Interpretation and Standards, Environmental Protection Agency, Ireland.

[14]. Environmental Resources Management Ltd. (1997), Environmental and Socioeconomic Characteristics of the Niger Delta. ERML, Lagos. 
[15]. Exploration and Production Forum (1994), North Sea produced water: Fate and Effects in the Marine Environment. Report No. 2.62/204. E and P, London.

[16]. Gbadebo, A., Taiwo, A., and Eghele, U. (2010) 'Environmental Impacts of Drilling Mud and Cutting Wastes from the Igbokoda Onshore Oil Wells, Southwestern Nigeria'. Indian Journal of Science and Technology 3 (5): 504-510

[17]. Harvey, R.G., (1997) Polycyclic Aromatic Hydrocarbon. Wiley, New York, NY.

[18]. Holdway, D. A. (2002) 'The Acute and Chronic Effects of Wastes Associated with Offshore Oil and Gas Production on Temperate and Tropical Marine Ecological Processes'. Marine Pollution Bulletin 44 (3): 185-203

[19]. Ikelegbe, A. (2005). 'The Economic of Conflict in the Oil Rich Niger Delta Region of Nige-ria' Journal of Third World Studies, 43 (2) 24-50.

[20]. Isehunwa, S. and Onovae, S. (2011) 'Evaluation of Produced Water Discharge in the Niger-Delta.'. Journal of Engineering \& Applied Sciences 6 (8) 66-71

[21]. Incardona, J.P., Collier, T.K., Scholz, N.L., (2004) Defects in Cardiac function Precede Mor-phological abnormalities in Fish embryos exposed to polycyclic aromatic hydrocarbons. Toxicol . Appl. Pharmacol. 196, 191205.

[22]. International Petroleum Industry Environmental Conservation Association (IPIECA), Iterna-tional Association Of oil and Gas Producer (OGP), (2009) Drilling Fluid and Health Risk Management : A Guide for personel , Managers and Health Professionals in the Oil and Gas Industry, IPIECA/OGP, Report 396, United Kingdom.

[23]. Jonathan, W. (2000) 'A survey of offshore oilfield Drilling waste and Disposal Techniques to Reduce the Ecological impact of sea Dumping"

[24]. kadafa, zakaria and Othman( 2012) ' Oil spillage and pollution in Nigeria organizational management and institutional framework '.Journal of Environmental and Earth Science 2 (4) 22-30

[25]. Kaur, G., Mandal, AK., Nihlani, M.c, Lal, B., (2009) Control of sulfidogenic bacteria in pro-duced water from the Kathloni oilfield in Northeast india. Int.Biodeterior. Biodegrad (63) 151-155

[26]. Kharaka,Y. K., and Otton. J.k., (2003) Environmental impacts of petroleum production: ini-tial results from the Osage-skiatook petroleum environmental research sites, Osage county, Oklahoma, Water-Resources investigations Report 03-4260.

[27]. Kia, M. (2009), The struggles for the survival of 12 million people in the Niger Delta. Envi-ronmental experts from UK, US and Nigeria affirmed that the Delta is the most polluted area in the world. http://nigerdeltasolidarity.wordpress.com.

[28]. Kinigoma, B.S (2001) "Effect of Drilling fluid Additives on the Niger Delta Environment: A case study of the souk oilfield 'Journal of Applied Science and Environmental management 5 (1) 57-61

[29]. Meier, S., Morton, H.c., Nyammer, G., Crosvik, B. E., Makhoting V., Geffen, A, Boltsov, S., Kvestad, K A., BohneKjersom, A., Goksoyr, A, Folkword, A., Klungsoyr, J., Svardal, A., (2010) Development of Atlantic Cod (Gadus Morhua) exposed produced water during early life stage on embryos larvae and juvenile fish. Journal of Marine environmental research (70) 383-394

[30]. Myers, M., Landahl. J.T., Krahn, M.M., B.B., (1991) Relationships between hepatic neo-plasms and related lesions and exposure to toxic chemicals in Marine fish from the united states west coast. Environ.Health perspect.(90) 7-15

[31]. Neff, J., Lee, K., Deblois, E.M., (2011) Produced water: overview of composition, fates and effects. In : Lee. K., Neff, J. (Eds), Produced water springer New York (chapter 1).

[32]. Nwilo, PC, Badejo, OT (2004) Management of Oil spill Dispersal Along the Nigerian Coastal Areas, Department of Surveying and Geoinformatics, University of Lagos.

[33]. Obire, O. and Amusan, F. (2003) 'The Environmental Impact of Oilfield Formation Water on a Freshwater Stream in Nigeria'. Journal of Applied Sciences and Environmental Management 7 (1): 61-66

[34]. Obi, C. (2000) 'Globalised images of Environental security in Africa', Review of African po-litical Economy, 27 (83), pp 47-62

[35]. Odeigah, P., Nurudeen, O., and Amund, O. O. (1997) 'Genotoxicity of Oil Field Wastewater in Nigeria'. Hereditas $126(2), 161-167$

[36]. Ogon EK (2006) Natural Resources abundance in Nigeria: from dependence to development. Resources policy, 33 , 168-174.

[37]. OGP (2005) 'Fate and Effect of Naturally Occurring Substances in produced water on the Marine Environment "Report no.364

[38]. Ogri, O. R. (2001). A Review of the Nigerian petroleum Industry and the Associated Envi-ronmental problems. Environmentalist, 21(1), 11-21

[39]. Ohimain, E. I. (ed.) (2003) Proceedings of the International Mine Water Association (IMWA) 2003 Congress, Johannesburg, South Africa. 'Environmental Impacts of Oil Mining Activities in the Niger Delta Mangrove Ecosystem' 503-517

[40]. Okoro, C. C. (2010) 'Microbiological Impacts of Produce Water Discharges in Nearshore Shallow Marine Waters Near Chevron's Escravos Tank Farm, Nigeria:. African Journal of Microbiology Research 4 (13), 1400-1407

[41]. Raji, AOY., Abejide, TS., (2013) 'An Assessment of Environmental Problems Associated with Oil Pollution and Gas Flaring in the Niger Delta Region Nigeria,C .1960s -2000', Ara-bian Journal of Bussness and Management Review 3 (3)

[42]. Roach,R., R. Carr,C. Howard, B.Cain, R.Carry, and C.Station (1992). 'Assessment of pro-duced water impacts in Galveston Bay System,' US Fish and wildlife Report, clear Lake Eco-logical services office, Houston, TX

[43]. Sagay, I.E (2001). The Extraction Industry in the Niger Delta and the Environment. The fourth annual lecture of the ANPEZ Centre for Environment and Development: Delivered at Port Harcourt, Nigeria. 
[44]. Scheren, P.C., A.C. Ibe, F.J. Janssen, and A.M. Lemmens, (2002) 'Environmental pollution in the Gulf of Guinea- a regional approach,' Marine pollution Bulletin, 44 (7). 633-641

[45]. Sturve, J., Hasselberg, L,. Faith, H., Celander, M., Forlin, L., (2006) Effects of North sea Oil and Alkylphenols on biomarker responses in Juvenile Atlantic cod (Gadus Morhua) Aquatic Toxicol 78, 573-578

[46]. Sil,A., Wakadikar K., Kumar S., Babu S., Sivagami S., Tandon S., Hettiaratchi P., (2012) ' ' Toxicity Characteristics of Drilling Mud and its Effect on Aquatic Fish Population', Journal of Hazardous, Toxic and Radioactive Waste 12 (16), 51-57.

[47]. Sundt, R.C., Brooks, S.,Grosvik, B.E., Pampanin, D.M., Farmen, E., Harman, C., Meier, S., (2011). Water Column Monitoring of offshore produced water Discharges. Compilation of previous Experience and suggestions For Future Survey Design. International Research insti-tute of Stavanger (IRIS), P. 123. Report no 7911854.

[48]. Torgeir.B, Jarle.K and Steinar, S. (2011) 'Environmental impact of produced water and Drill-ing waste discharge from Norwegian offshore petroleum Industry: Journal of Marine Envi-ronmental research 92 154-169

[49]. United Nations Development Programme (UNDP). (2006). Niger Delta human Development Report. Lagos (Nigeria): united Nations Development Programme.

[50]. Veil, J. A. (ed.) (2012) 'Potential Environmental Impact: of Produced water' International petroleum Environmental conference.

[51]. Veil, J (2015) U.S. Produced Water Volume and Management practices in 2012: A report prepaid for the Ground water protection council. Available at www.gwpc.org

[52]. Wills. MAJ (2000) Muddied waters: A survey of offshore oilfield drilling wastes and disposal techniques to reduce the ecological impact of sea dumping. Ekologicheskaya Vahkta Sakha-lina (Sakhalin Environment watch). Pp: 3236

[53]. World Health Organization (2011) Lead in Drinking-Water: Background document for de-velopment Of WHO Guidelines for Drinking-water Quality. 